\title{
Variable and complementary effects of herbivores on different life stages of bloom-forming macroalgae
}

\author{
Heike K. Lotze*, Boris Worm \\ Institut für Meereskunde, Düsternbrooker Weg 20, 24105 Kiel, Germany
}

\begin{abstract}
Increased nutrient loading favors macroalgal blooms in eutrophied coastal ecosystems. The main counteracting factor on this bottom-up support is top-down control by consumers. We asked (1) whether herbivore control on 2 bloom-forming macroalgae in the Baltic Sea varies between different algal life stages, (2) whether herbivores selectively feed on Enteromorpha spp. (Chlorophyceae) thereby supporting dominance of Pilayella littoralis (Phaeophyceae), and (3) whether various herbivore species differ in their effects. In comparative field and laboratory experiments, we analyzed herbivore pressure and selectivity on germling density and adult thalli of Enteromorpha spp. and $P$. littoralis. In the field, herbivores reduced macroalgal recruitment by $80 \%$ within $14 \mathrm{~d}$ indicating strong herbivore control at early life stages. Recruits of Enteromorpha spp. were significantly preferred over $P$. littoralis Adult thalli of both algae showed similar growth rates, but grazing rates were significantly higher on Enteromorpha spp. In laboratory experiments, Idotea chelipes (lsopoda), Littorina saxatilis (Gastropoda) and Gammarus locusta (Amphipoda) strongly reduced germling density, whereas effects of $L$. littorea were weak. I. chelipes and $L$. saxatilis significantly preferred germlings of Enteromorpha spp. over P. littoralis. I. chelipes had strong effects on adult Enteromorpha spp. but not on $P$. littoralis. The effects of $G$. locusta and $L$. littorea on both adult algae were smaller and not selective, and $L$. saxatilis did not feed on adults at all. Different herbivore feeding modes are discussed. We conclude that strong and selective herbivory on juvenile and adult Enteromorpha spp. favors dominance of $P$. littoralis in the Baltic. An effective control of macroalgal blooms in eutrophied areas can be supported by sustaining high herbivore density and species richness considering the variable and complementary effects of different herbivore species on different algal life stages.
\end{abstract}

KEY WORDS: Eutrophication - Macroalgal blooms - Species composition - Dominance - Grazing · Selectivity $\cdot$ Diversity $\cdot$ Feeding mode $\cdot$ Enteromorpha $\cdot$ Pilayella $\cdot$ Baltic Sea

\section{INTRODUCTION}

Over the last decades, humans have strongly enhanced the resource supply of aquatic plants by increasing nutrient loads to freshwater and marine ecosystems (Nixon 1995, Carpenter et al. 1998). As a consequence, fast-growing filamentous and foliose

\footnotetext{
-Present address: Biology Department, Dalhousie University, Halifax, Nova Scotia B3H 4J1, Canada.

E-mail: hlotze@is.dal.ca
}

algae continue to increase in abundance in coastal waters, where they can form destructive mass blooms that harm perennial macrophytes and benthic invertebrates (Duarte 1995, Fletcher 1996, Valiela et al. 1997, Raffaelli et al. 1998, Worm et al. 1999). The extent of such blooms varies considerably among different years and sites and cannot be explained by nutrient supply alone (Bonsdorff 1992, Fletcher 1996, Hauxwell et al. 1998). In addition, species composition within mass blooms is highly variable (Fletcher 1996), and the ability to predict the usually strong dominance of 1 species is generally restricted because many bloom-forming 
macroalgae share similar structural, physiological and life-history features (Raffaelli et al. 1998).

Herbivory has been proposed as a key variable that may help explain the variability in bloom abundance and composition (Valiela et al. 1997, Hauxwell et al. 1998, Lotze et al. 2000). Variable herbivore pressure and food selectivity have been shown to control plant species composition and abundance in many ecosystems (Lubchenco \& Gaines 1981, Davidson 1993, McNaughton et al. 1997, Sommer 1999). So far, herbivore effects on macroalgal blooms remain poorly investigated, but the recognition of their overall importance is growing (Warwick et al. 1982, Geertz-Hansen et al. 1993, Wilhelmsen \& Reise 1994, Hauxwell et al. 1998, Worm et al. 1999). Generally, fast-growing filamentous and foliose algae are highly vulnerable to herbivory because of low investment in structural or chemical defense (Littler \& Littler 1980, Hay \& Fenical 1988). On rocky shores, strong herbivory on annual algae was shown to favor dominance of perennials (Lubchenco 1986), whereas selective grazing among different perennial species determined their species composition (Denton \& Chapman 1991, Schaffelke et al. 1995). We hypothesize that intense herbivore pressure may suppress macroalgal blooms, and herbivore food selectivity may alter species composition and dominance patterns within blooms.

In the Baltic Sea, macroalgal blooms are typically composed of the filamentous brown alga Pilayella littoralis dominating over the foliose green-tide alga Enteromorpha intestinalis. These 2 species have very similar ecophysiological capacities (growth, nutrient uptake) at the adult stage, but $P$. littoralis is able to germinate at lower temperatures, which was proposed to be a seasonal advantage for this species (Lotze et al. 1999, Lotze \& Schramm 2000). Field experiments revealed that the population development of Enteromorpha spp. and $P$. littoralis was affected by overwintering patterns, the timing of germination, nutrient availability and grazer presence (Lotze et al. 2000). In these experiments, the presence of grazers negatively affected the occurrence of $E n$ teromorpha spp. and favored $P$. littoralis. We wanted to know how herbivore effects differ among different algal life stages, and whether there is an escape in size from herbivore control (Petraitis 1987, Wilhelmsen \& Reise 1994). Moreover, we asked whether herbivores selectively feed on Enteromorpha spp. compared to $P$. littoralis in both early and adult life stages, and whether 4 herbivore species that co-occur in the Baltic Sea differ in their effects. In order to answer these questions, we compared herbivore effects on germling abundance and adult thallus length of Enteromorpha spp. and $P$. littoralis in a series of field and laboratory experiments.

\section{MATERIALS AND METHODS}

Study site and species. This study was carried out in 1997 in Maasholm Bay, outer Schlei Fjord (54 41' N, $\left.10^{\circ} 0^{\prime} \mathrm{E}\right)$, western Baltic Sea, Germany. This tideless shallow bay ( 0 to $1.5 \mathrm{~m}$ ) has a sandy bottom scattered with rocks and boulders providing abundant substrata for seaweed colonization. The benthic vegetation is dominated by perennial Fucus vesiculosus L. In spring and early summer, F. vesiculosus plants become overgrown with epiphytic Pilayella littoralis (L.) Kjellm and Enteromorpha intestinalis L., which also occur abundantly on rocks and as free-floating algal mats. Within the genus Enteromorpha, E. intestinalis is the dominant species (>80\%), but E. prolifera (O. F. Müller) J. Agardh and E. clathrata (Roth) Greville co-occur in summer. In the germling stage, these species can hardly be distinguished and are therefore treated hereafter as Enteromorpha spp. Herbivores associated with the Fucus community are isopods (>95\% Idotea chelipes [Pallas], $<5 \%$ I. balthica [Pallas]), amphipods (mainly Gammarus locusta [L.], <25\% G. salinus [Spooner] and G. zaddachi [Sexton]), and littorinid snails (Littorina saxatilis [Olivi], L. littorea [L.]).

Field experiments. Experimental design: We used a large year-round cage experiment as a platform for our short-term (1 to 2 wk) grazing experiments. The large experiment was designed to study the effects of herbivores, of overwintering in an algal propagule bank, and of summer nutrient enrichment on population development of macroalgae on rocks (Lotze et al. 2000). The 3 experimental factors were combined in a completely crossed design $(2 \times 2 \times 2)$ with 48 experimental units and 4 replicates per treatment combination arranged in a randomized block design (Hurlbert 1984). The experiment was located at $0.8 \mathrm{~m}$ water depth in the zone dominated by Fucus vesiculosus and experimental units were $3 \mathrm{~m}$ apart. Herbivore presence was manipulated using cages $(25 \times 25 \times 25 \mathrm{~cm})$ made of a stainless steel frame covered with $1 \mathrm{~mm}$ transparent polyethylene mesh. Herbivores $>1 \mathrm{~mm}$ were excluded from closed cages (No herbivory), while cages with 1 side cut open allowed herbivore access (Herbivory). In the main experiment, closed and open cages were compared to analyze herbivore effects. In a parallel control experiment, we evaluated possible cage artifacts on dependent variables by comparing open cages (Herbivory) with uncaged plots (Cage controls). For the large experiment, each unit had a flat granite rock (15 to $20 \mathrm{~cm}$ ) from the study site to study macroalgal colonization and development from February to December 1997. Half of the rocks were sterilized to exclude overwintering microscopic stages; the other half of the rocks were left untreated but had no macroscopic vegetation at the beginning of the experiment. Nutrient enrichment was 
included as an additional factor in summer, after the here-presented grazing experiments were performed in June. Because nutrient enrichment was not yet started and the algal propagule bank had no effect on the dependent variables of our grazing experiments (ANOVAs, propagula bank effect on germling densities, growth rates, grazer densities, $p>0.05$ ) we pooled herbivore treatments over treatments with and without propagule bank (Herbivory, No herbivory, Cage control, $n=16$ ). The cages were brushed weekly to prevent fouling. Light measurements (LI-COR LI-192SA) inside and outside the cages revealed reduction of light intensity by $8 \%$ due to attenuation by the polyethylene mesh which we judged negligible.

Effects of herbivores on new recruitment: In the end of May 1997, we investigated the effects of herbivores on new recruitment (settlement, germination and subsequent growth) of macroalgal propagules. We exposed 1 sterilized ceramic tile $(5 \times 10 \mathrm{~cm})$ per plot as a settlement substratum in cages (closed, open) and on uncaged plots ( $n=16$ ). After $14 \mathrm{~d}$, germling abundance was determined with a dissecting microscope (mean of 6 subsamples of $4 \times 4 \mathrm{~mm}$ per tile). Only germlings of Enteromorpha spp, and Pilayella littoralis occurred. We calculated germling densities $\mathrm{cm}^{-2}$ for each species. Herbivore effects on total germling density were analyzed by 1-way ANOVA. Untransformed data showed homogeneity of variances which was checked by Cochran's test.

Herbivore preference among germlings of Enteromorpha spp. and Pilayella littoralis was analyzed with a paired $t$-test as recommended by Peterson $\&$ Renaud (1989), which eliminates the problem of independence. This analysis tested the null-hypothesis that the difference between recruit densities of $P$. littoralis and Enteromorpha spp. is equal in 'Herbivory' and 'No herbivory' treatments, thus there is no herbivore preference. The $t$-test is: $t=\left(m_{E}-m_{C}\right) / \sqrt{ }\left(s^{2} / n_{E}-s^{2} / n_{C}\right)$, where $m_{\mathrm{E}}=$ mean of differences in germling density in experimental treatments (Herbivory), $m_{C}=$ mean of differences in controls (No herbivory), $s^{2}=$ variance and $n=$ number of replicates. Data were log-transformed to achieve homogeneity of variances.

Effects of herbivores on adults: Herbivore effects on adult algal thalli were quantified in a field assay in mid-May. In a first trial, 48 pieces of Enteromorpha intestinalis thalli with standard width $(0.5 \mathrm{~cm})$ and length $(6.0 \mathrm{~cm})$ were cut from the middle part of freshly collected thalli and fixed with plastic clothes pins. One piece of $E$. intestinalis was then exposed $15 \mathrm{~cm}$ above the substratum in each plot (Herbivory, No herbivory, Cage control, $n=16$ ). After $8 d$, thallus length was remeasured with a ruler to a precision of $1 \mathrm{~mm}$. From length measurements we calculated the relative daily growth (or loss) rate: $\mathrm{RGR}=\left(\ln I_{2}-\ln I_{1}\right) /\left(t_{2}-t_{1}\right)$, where
$I=$ length, and $t=$ time. In a subsequent independent assay, bundles of adult Pilayella littoralis thalli of standard width $(0.5 \mathrm{~cm})$ and length $(6.0 \mathrm{~cm})$ were used. We performed 2-way factorial ANOVA (factors: herbivory, species, $2 \times 2$ ) on algal growth data with RGR as the dependent variable. The untransformed data achieved homogeneity of variances. The abundance of herbivores was counted in the herbivore treatments (open cage, uncaged plots, $25 \times 25 \mathrm{~cm}$ ). The cage effect on herbivore density was analyzed by 1-way ANOVA for each herbivore species separately, and data were logtransformed to achieve homogeneity of variances.

Laboratory experiments. Feeding choice on germlings: At the beginning of June, we compared feeding preference among the 4 most abundant herbivore species in the field (Idotea chelipes, Gammarus locusta, Littorina littorea, L. saxatilis) between germlings of Enteromorpha spp. and Pilayella littoralis. To establish dense stands of algal germlings as a food source, 6 sterilized ceramic tiles $(10 \times 10 \mathrm{~cm})$ were exposed in the water column at the study site for $24 \mathrm{~h}$. The tiles were then cultivated separately for $12 \mathrm{~d}$ in $500 \mathrm{ml}$ Provasoli enriched seawater (Starr \& Zeikus 1987) with germanium dioxide $\left(0.5 \mathrm{mg} \mathrm{l}^{-1}\right)$ added to prevent growth of diatoms. The cultivation temperature was $15^{\circ} \mathrm{C}$ with a light intensity of $100 \mu \mathrm{mol}$ photons $\mathrm{m}^{-2} \mathrm{~s}^{-1}$ in a $14 \mathrm{~h}$ light:10 $\mathrm{h}$ dark cycle. After cultivation, initial germling density per tile was determined with a dissecting microscope (mean of 10 subsamples of $4 \times$ $4 \mathrm{~mm}$ per tile). The tiles were cut into 4 pieces, and each piece was offered to a different herbivore species ( 1 individual per piece, $n=6$ ) for $48 \mathrm{~h}$ in a 11 glass beaker, filled with $300 \mathrm{ml}$ freshly collected seawater. Herbivores were collected $1 \mathrm{~d}$ prior to the experiment and kept in $10 \mathrm{l}$ aquaria filled with fresh seawater until the initiation of the experiment. After the feeding trial, final germling density was determined. We analyzed selectivity of single herbivore species between Enteromorpha spp. and Pilayella littoralis germlings but did not compare absolute consumption rates because of large size differences among herbivore species. Germlings were 100 to $400 \mu \mathrm{m}$ long in the beginning and did not exceed $600 \mu \mathrm{m}$ after $48 \mathrm{~h}$ (growth rate of ca $20 \%$ $\mathrm{d}^{-1}$ ). Autogenic changes in germling size and density were assumed to be negligible within the experimental period of $48 \mathrm{~h}$, because earlier experiments revealed that distinct changes in germling density only occur on a time scale of 3 to $4 \mathrm{wk}$ in the course of new reproduction, germination, and mortality (Lotze et al. 1999). Statistical analysis of herbivore preference was performed by paired $t$-tests, 2-tailed (Peterson \& Renaud 1989, Howell 1992) which tested the null-hypothesis that consumption rate of Enteromorpha spp. and $P$. littoralis was equal. The dependent variable, a percentage reduction of germling density, was angularly 
Table 1. Herbivore food preference between recruits of Enteromorpha spp. and Pilayella littoralis. Result of a paired $t$-test (Peterson \& Renaud 1989) on means of differences between germling densities of Enteromorpha (E) and Pilayella (Pi) in treatments with and without herbivores. Data are log-transformed to achieve homogeneity of variances. Tabled test limits are $t_{16,2}=2.75$ $(p=0.01), 3.65(p=0.001)$

\begin{tabular}{|lccccc|}
\hline Treatment & Mean of $(\mathrm{E}-\mathrm{P})$ & Variance, $s^{2}$ & $\mathrm{n}$ & $\mathrm{t}$-value & Conclusion \\
\hline No herbivory & 0.0598 & 0.0559 & 16 & & $\mathrm{p}<0.01$ \\
Herbivory & -0.1741 & 0.0287 & 16 & -3.2168 & \\
\hline
\end{tabular}

transformed to achieve homogeneity of variances (Sokal \& Rohlf 1995).

Feeding choice on adults. The feeding preference of the above 4 herbivore species between adult Enteromorpha intestinalis and Pilayella littoralis was investigated in early June. Petri dishes (9 $\mathrm{cm}$ in diameter) were rinsed with freshly collected seawater several times and filled with $80 \mathrm{ml}$ seawater. Algal pieces of a standard size $(0.2 \times 3.0 \mathrm{~cm})$ were cut from freshly collected material. We used middle parts of 8 to $10 \mathrm{~cm}$ long algal thalli. One piece of each algal species was placed at $6 \mathrm{~cm}$ distance from the other species in a petri dish. After $30 \mathrm{~min}$, allowing for development of a possible chemical gradient (M. Wahl pers. comm.), 1 herbivore individual was added per treatment, each species in 20 replicates. Within the feeding trial, we counted how many thalli were completely $(100 \%)$ consumed after $5,19,27,42,48 \mathrm{~h}$. These data were not statistically analyzed.

\section{RESULTS}

\section{Herbivore abundance}

In the field experiments, herbivores were successfully excluded from closed cages (No herbivory). In 'Herbivory' treatments, Littorina saxatilis (446 \pm $\left.77 \mathrm{~m}^{-2}\right)$, Gammarus spp. $\left(339 \pm 63 \mathrm{~m}^{-2}\right)$, and Idotea spp. $\left(499 \pm 108 \mathrm{~m}^{-2}\right)$ were the most abundant herbivores, followed by $L$. littorea $\left(4 \pm 4 \mathrm{~m}^{-2}\right)$. Densities of Gammarus spp. and L. littorea were similarly high in open cages (Herbivory) and uncaged plots (Cage controls) and thus not affected by the cage structure (ANOVA, no cage effect on Gammarus spp.: $F_{1,21}=0.77, \mathrm{p}=0.39$; L. littorea: $F_{1,21}=1.17, \mathrm{p}=0.29$ ). Idotea spp. were slightly attracted by open cages (cage effect, $F_{1,21}=$ $4.71, \mathrm{p}=0.042$ ), which might be an effect of shelter or enhanced food supply compared to uncaged plots. $L$. saxatilis, however, was strongly reduced in open cages compared to uncaged plots (cage effect, $F_{1,21}=20.57$, $\mathrm{p}=0.0002$ ) with densities of $1306 \pm 227 \mathrm{~m}^{-2}$ in the latter. This was likely caused by the weekly brushing of cages after which slow-moving snails needed time to re-invade, while more mobile amphipods and isopods could rapidly re-enter open cages. The strong reduction of $L$. saxatilis density in open cages compared to uncaged plots resulted in an overall reduction of herbivore pressure in the main experiment, thus, herbivore effects were conservatively estimated in our experiments.

\section{Effects of herbivores on new recruitment}

In the field, new recruitment of both Enteromorpha spp. and Pilayella littoralis on tiles was strongly reduced by herbivores (Fig. 1). Herbivores significantly reduced total germling density by $55 \%\left(F_{1,30}=18.31\right.$, $\mathrm{p}=0.0002$ ) within $14 \mathrm{~d}$. Thereby, germling density of Enteromorpha spp. was significantly more strongly reduced by herbivores than that of $P$. littoralis (Table 1) indicating that Enteromorpha spp. germlings were the preferred food source over P. littoralis. In 'Cage control' plots, total germling density was reduced by $80 \%$, which was significantly higher than in 'Herbivory' treatments (cage effect, $F_{1,30}=9.85, \mathrm{p}=$ 0.0038 ), but the relative abundance of both algae was similar. The increased algal recruitment in 'Herbivory' treatments compared to 'Cage controls' was most likely caused by the reduced herbivore pressure (see above) in open cages. All other possible cage effects

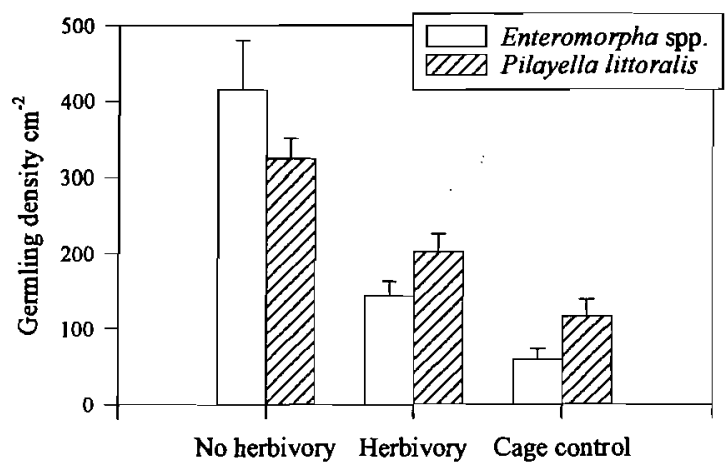

Fig. 1. Effects of herbivores on new recruitment (settlement, germination and subsequent growth) of Enteromorpha spp. and Pilayella littoralis in the field. Ceramic tiles were exposed in closed cages (No herbivory), open cages (Herbivory), and on uncaged plots (Cage control). After $14 \mathrm{~d}$, developed germlings were counted (means $\pm 1 \mathrm{SE}, \mathrm{n}=16$ ) 


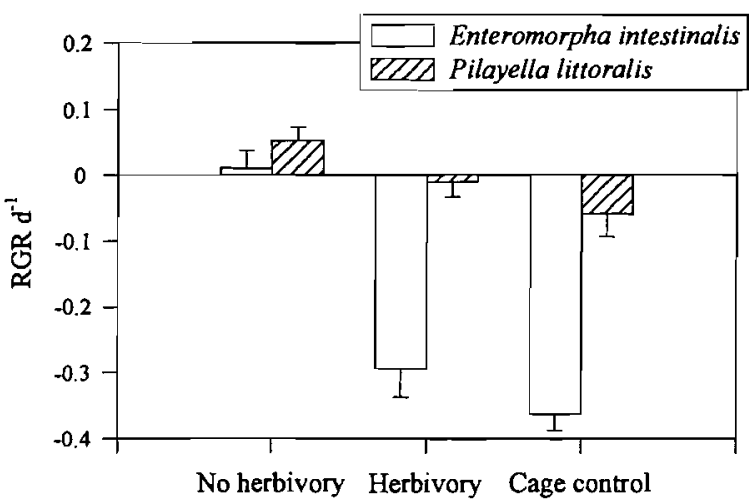

Fig. 2. Relative daily growth (or loss) rate (RGR) of adult Enteromorpha intestinalis and Pilayella littoralis in closed cages (No herbivory), open cages (Herbivory), and on uncaged plots (Cage control) in the field (means $\pm 1 \mathrm{SE}_{1} \mathrm{n}=16$ ). Refer to Table 2 for statistical analysis

(e.g. decreased light penetration, increased sedimentation, decreased water flow) would have decreased algal performance in open cages compared to uncaged plots.

\section{Effects of herbivores on adults}

In the absence of herbivores, net growth rates (length increase) of adult Enteromorpha intestinalis and Pilayella littoralis were similar under field conditions ( $t$-test, $t_{16,2}=1.73, \mathrm{p}=0.20$ ). Relative daily loss rates in 'Herbivory' treatments, however, were $29.3 \%$ in E. intestinalis and $1.1 \%$ in P. littoralis (Fig. 2). The stronger reduction of adult $E$. intestinalis by herbivores compared to $P$. littoralis resulted in a significant herbivory $\times$ species interaction (Table 2) indicating that $E$. intestinalis was the preferred food source. In 'Cage control' plots, relative loss rates of both algae were slightly enhanced, but no cage artifact occurred $\left(F_{1,57}=\right.$ $3.14, p=0.08)$. Despite separate assays for each algal species, herbivores in the field had the choice between $E$. intestinalis, $P$. littoralis and other algae present at the study site.

Table 2. Results of 2-way ANOVA on effects of herbivores on relative growth (or loss) rate (RGR) of adult Enteromorpha intestinalis and Pilayella littoralis. No cage artifacts $\left(F_{1,57}=\right.$ $3.140, p=0.082$ ) occurred

\begin{tabular}{|lcccc|}
\hline Source & df & MS & F-ratio & p-value \\
\hline Herbivory $(\mathrm{H})$ & 1 & 0.489 & 35.719 & 0.0001 \\
Species $(\mathrm{S})$ & 1 & 0.453 & 31.457 & 0.0001 \\
$\mathrm{H} \times \mathrm{S}$ & 1 & 0.205 & 14.716 & 0.0003 \\
Block & 3 & 0.021 & & \\
Residual & 57 & 0.014 & & \\
\hline
\end{tabular}

\section{Feeding choice and feeding patterns on germlings}

In laboratory feeding-choice tests, the 4 main herbivore species consumed more germlings of Enteromorpha spp. than Pilayella littoralis out of a dense germling stand of both algae (Fig. 3). These trends were statistically significant in Idotea chelipes $\left(t_{16,2}=3.87\right.$, $\mathrm{p}=0.012)$ and Littorina saxatilis $\left(t_{16,2}=4.38, \mathrm{p}=0.007\right)$, and insignificant in $L$. littorea (but note a trend towards increased consumption of Enteromorpha spp. $t_{16,2}=$ 2.61, $\mathbf{p}=0.059)$ and Gammarus locusta $\left(t_{16,2}=0.48\right.$, $\mathrm{p}=0.65$ ). Average initial germling densities were $340.2 \pm 36.9 \mathrm{~cm}^{-2}(\mathrm{n}=6)$ in Enteromorpha spp. and $325.7 \pm 21.9 \mathrm{~cm}^{-2}$ in P. littoralis.

Grazing patterns were distinctly different among herbivore species. Littorina saxatilis left cleared feeding trails through the germling turf ('bulldozer effect'). Idotea chelipes shortened the germling turf as a whole with many truncated germling stumps left over ('lawnmower effect'). Gammarus locusta consumed entire germlings and thinned rather than shortened the germling turf ('picker effect'). L. littorea showed no clear feeding patterns.

\section{Feeding choice on adults}

To investigate whether feeding patterns of herbivores on germlings are paralleled in adult algae, we arranged similar feeding preference tests between adult thalli of Enteromorpha intestinalis and Pilayella littoralis in the laboratory. Only Idotea chelipes showed a distinct effect on adult thalli with a clear

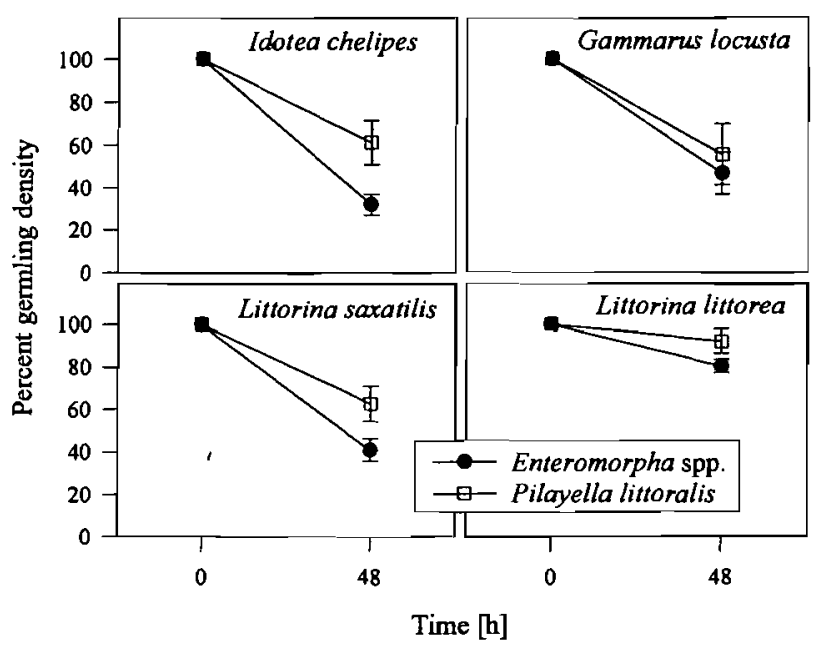

Fig. 3. Feeding choice tests on germlings of Enteromorpha spp. and Pilayella littoralis with 4 herbivore species in the laboratory. Mixed stands of germlings of both algae were of fered to individual herbivores for $48 \mathrm{~h}$. Shown are percent initial and remaining germling density $\mathrm{cm}^{-2}$ (means $\pm 1 \mathrm{SE}, \mathrm{n}=6$ ) 


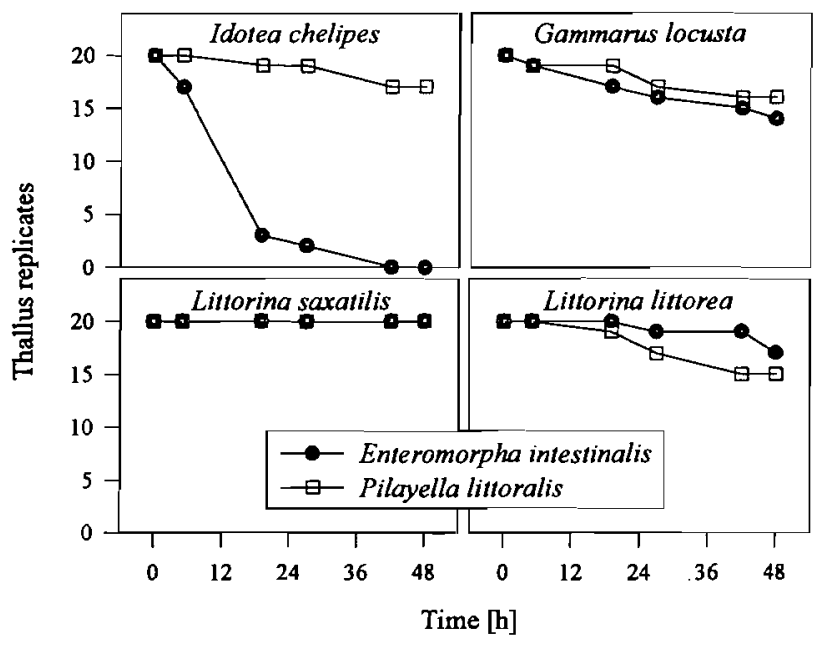

Fig. 4. Feeding preference of 4 herbivore species on adult thalli of Enteromorpha intestinalis and Pilayella littoralis in the laboratory. In 20 replicates, individuals of single herbivore species had the choice between thallus pieces of each algae. Graphs show the remaining replicates over the experimental period

preference for $E$. intestinalis over $P$. littoralis after $19 \mathrm{~h}$ (Fig. 4). Gammarus locusta and Littorina littorea had only slight effects with no clear preference for 1 of the 2 species. $L$, saxatilis showed no effect at all, not even feeding marks were detected.

\section{DISCUSSION}

Our results indicate strong herbivore control of 2 common bloom-forming macroalgae, Enteromorpha spp. and Pilayella littoralis. Two patterns emerged: (1) herbivore effects were strong at both germling and adult life stages, and (2) Enteromorpha spp. was the preferred food source over $P$. littoralis at both life stages. Interestingly, the effects of single herbivore species varied with algal life stage in a complementary fashion suggesting the importance of life-stage specific and species-specific selectivity in addition to total grazing pressure. While intense herbivore pressure may reduce bloom formation, selective herbivory on recruits and adults of Enteromorpha spp. may favor dominance of $P$. littoralis in macroalgal blooms in the Baltic Sea.

Herbivores had strong impacts on bloom-forming Enteromorpha spp. and Pilayella littoralis in our shortterm field tests as expected from results of a yearround study (Lotze et al. 2000). These effects were caused by a herbivore assemblage of Idotea spp., Gammarus spp., and Littorina spp., which is typical for the western Baltic Sea as well as most North Atlantic rocky shorelines (Geertz-Hansen et al. 1993, Worm \&
Chapman 1998). The same herbivore guild was shown to prevent mass accumulation of green Ulva lactuca in Roskilde Fjord, Denmark (Geertz-Hansen et al. 1993). In Southern England, crustacean herbivores did not prevent bloom formation but seemed responsible for the breakdown of Enteromorpha spp. mats on soft bottoms during the summer (Warwick et al. 1982). These examples show that herbivores are capable of controlling the extent of macroalgal blooms. However, herbivore effects depend on the abundance and distribution of herbivore species, which are affected by predation (Warwick et al. 1982), habitat availability (Salemaa 1987, Boström \& Mattila 1999), seasonality in the environment (Petraitis 1983, Steele \& Whittick 1991), and nutrient status of the system (Hauxwell et al. 1998, Worm et al. 2000).

Herbivore control in our field experiments was strong at the adult and germling stage. The effects of herbivores on early life stages have been overlooked for a long time, although foraging activities by herbivores may constitute the greatest source of mortality to early post-settlement stages of macroalgae (Vadas et al. 1992). We found that herbivores in the field reduced the germling density of Pilayella littoralis and Enteromorpha spp. on tiles by $80 \%$ within $14 \mathrm{~d}$. In the laboratory, crustacean grazers reduced the germination rate of settled Enteromorpha spp. propagules by 93 to $95 \%$ within $7 \mathrm{~d}$ (Lotze et al. 1999). An effective herbivore control at early life stages was also found on rocky shores in New England and soft-sediments in the german Wadden Sea, where few littorinid snails were able to prevent Enteromorpha spp. from colonizing, but high snail densities were required to control an adult Enteromorpha spp. canopy (Petraitis 1987, Wilhelmsen $\&$ Reise 1994). These results indicate that herbivores have the potential to inhibit the formation of macroalgal blooms, but that there may be an escape in size. In our experiments, however, losses to herbivory were also intense at the adult stage and could not be compensated by growth.

At both the germling and adult stage, Enteromorpha spp. were more strongly reduced by herbivores than Pilayella littoralis. This food preference may be caused by chemical, structural, morphological, or nutritional differences between the 2 algae which are so far untested. Chemical and structural defense against herbivores are common in perennial seaweeds but are often lacking in opportunistic algae (Littler \& Littler 1980, Gaines 1985, Hay \& Fenical 1988). Generally, green algae are the group of macroalgae least likely to contain herbivore deterrents, whereas most brown algae may contain polyphenolic anti-herbivore compounds (Hay \& Fenical 1988).

The effects of single herbivore species varied with algal species and life stage. Idotea chelipes had the 
strongest effects on both germlings and adults of Enteromorpha spp., while its effects on Pilayella littoralis were smaller but still effective in both life stages. In contrast, Littorina saxatilis heavily reduced germlings of both algae with a preference for Enteromorpha spp. but did not feed on adults at all. The selective effects of these 2 grazers acting on different algal life stages may favor dominance of $P$. littoralis over Enteromorpha spp. in macroalgal blooms in the Baltic Sea. Gammarus locusta was not selective and showed strong effects on germlings but only moderate effects on adults of both algae. This species thus may contribute to the overall reduction of bloom-forming algae in the field. In turn, $L$. littorea had only weak effects in our experiments and most likely also in the field considering its low abundances. The whole pattern might be further complicated by life-stage specific differences within herbivore species, for example when juvenile grazers depend on different food sources compared to adults. This has been discussed for $I$. balthica in the northern Baltic Sea, where adults live and feed within perennial macrophytes (Fucus spp., Zostera spp.), but juveniles preferred filamentous algae in the splash zone as a habitat and food source (Salemaa 1987).

Beneath quantitative and selective effects of herbivores, the resulting grazer effect may also differ with the feeding mode. Parker et al. (1993) showed that littorinid snails can prevent the establishment of both micro- and macroalgae at the microscopic level, whereas gammarid amphipods are ineffective at grazing microalgae and prostrate macroalgae from the substratum, but significantly graze erect macroalgae. We found Littorina saxatilis ('bulldozer' type) to leave distinct feeding trails, while Gammarus locusta picked single germlings out of the turf thereby thinning the germling stand. Idotea chelipes shortened the germling turf ('lawn-mower') but did not remove recruits completely. Both isopods and amphipods use their mandibles to bite off small portions of algae, while other mouthparts assist in handling the food items. Littorinids in contrast scrape the substratum with their radula (Hawkins \& Hartnoll 1983). Consequently, after the exclusion of isopods and amphipods, germlings are able to regrow, whereas littorinids leave bare substratum (Lotze et al. 1999, Sommer 1999). Thus, grazing by $L$. saxatilis may effectively prevent formation of blooms at early life stages, while grazing by $I$. chelipes and $G$. locusta reduces germling and adult stands.

Looking at a year-round picture, the effects of single herbivore species may not act at the same time. At our site, herbivore occurrence and abundance strongly varied with season (Lotze et al. 2000), which can be caused by predation (Boström \& Mattila 1999, Worm et al. 2000) and patterns of reproduction (Salemaa 1987).
In early spring, when the population development of Enteromorpha spp. and Pilayella littoralis started, Gammarus spp. were most abundant in March-April, followed by Littorina saxatilis. While the abundance of Gammarus spp. dropped in May, $L$. saxatilis increased in abundance and occurred throughout summer. These 2 species may thus have the potential to suppress bloom formation in spring at early life stages. In turn, Idotea spp. was rare in spring but most abundant in July-August, and thus may contribute to the reduction of established algae and the summer breakdown of blooms.

Our results suggest that not only the quantity (intensity, frequency) but also the quality (selectivity, feeding mode) of grazing are important to determine overall grazing effects on macroalgal blooms. The importance of both quantity and quality of herbivory was also demonstrated for algal diversity and community structure (Gaines 1985, Sommer 1999). Considering all the above mentioned variations in quantity and quality of grazing effects, an effective control of macroalgal blooms may be most likely performed by a diverse herbivore guild rather than a single 'keystone' grazer species. Such 'diffuse consumption', where the overall effect is shared by several consumers of similar importance, appears to regulate species composition and diversity in various coastal communities (Robles \& Robb 1993, Menge et al. 1994, Sommer 1999).

We conclude that herbivore control of macroalgal blooms may increase with increasing herbivore abundance and diversity. Today, however, herbivore populations are vulnerable to various human influences in coastal ecosystems. Increasing anthropogenic nutrient enrichment counteracts herbivore control by increasing algal growth and overcompensating grazing losses (Hauxwell et al. 1998, Lotze et al. 2000). By stimulating phytoplankton blooms, nutrient loading causes enhanced sedimentation, which leads to a deterioration of the living and foraging conditions of snails which effectively graze mainly on hard substratum (Wilhelmsen \& Reise 1994). Toxins such as the antifouling agent tributyltin (TBT) were shown to impair reproductive ability in snails such as Littorina littorea (Schulte-Oehlmann et al. 1996). Pesticides in salmon aquaculture target crustacean fish parasites, but drastically reduce crustacean grazer populations in the vicinity (B.W. pers. obs.). The widespread declines of perennial vegetation following eutrophication (Valiela et al. 1997, Raffaelli et al. 1998, Worm et al. 1999) can lead to habitat loss for herbivores which are often closely associated to the perennial canopy (Salemaa 1987). In combination, these anthropogenic influences limit natural herbivore control on bloom-forming, macroalgae which may cause increased bloom frequency and intensity with devastating consequences for coastal ecosystems (Valiela et al. 1997). 
Acknowledgements. We thank U. Sommer, A. R. O. Chapman, T. B. H. Reusch and A. F. Peters for helpful comments on the manuscript. This work was funded by individual grants to H.K.L. and B.W. by the German Ministry of Education, Science and Technology, HSP III program.

\section{LITERATURE CITED}

Bonsdorff E (1992) Drifting algae and zoobenthos-effects on settling and community structure. Neth $J$ Sea Res 30: $57-62$

Boström C, Mattila J (1999) The relative importance of food and shelter for seagrass-associated invertebrates: a latitudinal comparison of habitat choice by isopod grazers. Oecologia 120:162-170

Carpenter SR, Caracao NF, Correll DL, Howarth RW, Sharpley AN, Smith VH (1998) Nonpoint pollution of surface waters with phosphorous and nitrogen. Ecol Appl 8: 559-568

Davidson DW (1993) The effects of herbivory and granivory on terrestrial plant succession. Oikos 68:23-35

Denton AB, Chapman ARO (1991) Feeding preferences of gammarid amphipods among four species of Fucus. Mar Biol 109:503-506

Duarte CM (1995) Submerged aquatic vegetation in relation to different nutrient regimes. Ophelia 41:87-112

Fletcher RL (1996) The occurrence of 'green tides' - a review. In: Schramm W, Nienhuis PH (eds) Marine benthic vegetation - recent changes and the effects of eutrophication. Springer-Verlag, Berlin, p 7-44

Gaines S (1985) Herbivory and between-habitat diversity: the differential effectiveness of defenses in a marine plant. Ecology 66:473-485

Geertz-Hansen O, Sand-Jensen $\mathrm{K}$, Hansen DF; 'Christiansen A (1993) Growth and grazing control of abundance of the marine macroalga Ulva lactuca $\mathrm{L}$. in a eutrophic Danish estuary. Aquat Bot 46:101-109

Hauxwell J, McClelland J, Behr PJ, Valiela I (1998) Relative importance of grazing and nutrient controls of macroalgal biomass in three temperate shallow estuaries. Estuaries 21:347-360

Hawkins SJ, Hartnoll RG (1983) Grazing of intertidal algae by marine invertebrates. Oceanogr Mar Biol Annu Rev 21: 195-282

Hay ML, Fenical W (1988) Marine plant-herbivore interactions: the ecology of chemical defense. Annu Rev Ecol Syst 19:111-145

Howell DC (1992) Statistical methods for psychology. Duxbury Press, Belmont

Hurlbert SH (1984) Pseudoreplication and the design of field experiments. Ecol Monogr 54:187-211

Littler MM, Littler DS (1980) The evolution of thallus form and survival strategies in benthic marine macroalgae: field and laboratory tests of a functional form model. Am Nat 116:25-44

Lotze HK, Schramm W (2000) Can ecophysiological traits explain species dominance patterns in macroalgal blooms? J Phycol 36:287-295

Lotze HK, Schramm W, Schories D, Worm B (1999) Control of macroalgal blooms at early developmental stages: Pilayella littoralis versus Enteromorpha spp. Oecologia 119: $46-54$

Lotze HK, Worm B, Sommer U (2000) Propagule banks, herbivory and nutrient supply control population development and dominance patterns in macroalgal blooms. Oikos 89:46-58
Lubchenco J (1986) Relative importance of competition and predation: early colonization by seaweeds in New England. In: Diamond J, Case TJ (eds) Community ecology. Harper \& Row, New York, p 537-555

Lubchenco J, Gaines SD (1981) A unified approach to marine plant-herbivore interactions I: populations and communities. Annu Rev Ecol Syst 12:405-437

McNaughton SJ, Banyikwa FF, McNaughton MM (1997) Promotion of the cycling of diet-enhancing nutrients by African grazers. Science 278:1798-1800

Menge BA, Berlow EL, Blanchette CA, Navarette SA, Yamada SB (1994) The keystone species concept: variation in interaction strength in a rocky intertidal habitat. Ecol Monogr 64:249-286

Nixon SW (1995) Coastal marine eutrophication: a definition, social causes, and future concerns. Ophelia 41: $199-219$

Parker T, Johnson CR, Chapman ARO (1993) Gammarid amphipods and littorinid snails have significant but different effects on algal succession in littoral fringe tidepools. Ophelia 38:69-88

Peterson $\mathrm{CH}_{1}$ Renaud PE (1989) Analysis of feeding-preference experiments. Oecologia 80:82-86

Petraitis PS (1983) Grazing patterns of the periwinkle and their effects on sessile intertidal organisms. Ecology 64 522-533

Petraitis PS (1987) Factors organizing rocky intertidal communities of New England: herbivory and predation in sheltered bays. J Exp Mar Biol Ecol 109:117-136

Raffaelli DG, Raven J, Poole L (1998) Ecological impact of macroalgal blooms. Oceanogr Mar Biol Annu Rev 36 : 97-125

Robles C, Robb J (1993) Varied carnivore effects and the prevalence of intertidal algal turfs. J Exp Mar Biol Ecol 166:65-91

Salemaa H (1987) Herbivory and microhabitat preferences of Idotea spp. (Isopoda) in the northern Baltic Sea. Ophelia $27: 1-16$

Schaffelke B, Evers D, Walhorn A (1995) Selective grazing of the isopod Idotea baltica between Fucus evanescens and $F$. vesiculosus from Kiel Fjord (western Baltic). Mar Biol $124: 215-218$

Schulte-Oehlmann U, Oehlmann J, Watermann B, Bauer B, Ide I, Fiorino P (1996) Effekte von Tributylzinn (TBT) aus Antifoulinganstrichen auf Schneckenpopulationen in der Ostsee. In: Lozán JL, Lampe $\mathbf{R}$, Matthäus W, Rachor E, Rumohr $\mathrm{H}$, von Westernhagen $\mathrm{H}$ (eds) Warnsignale aus der Ostsee. Parey, Berlin, p 176-179

Sokal RS, Rohlf FJ (1995) Biometry, 3rd edn. WH Freeman, San Francisco

Sommer U (1999) The impact of herbivore type and grazing pressure on benthic microalgal diversity. Ecol Letters 2: $65-69$

Starr RC, Zeikus JA (1987) UTEX - the culture collection of algae at the University of Texas at Austin. J Phycol 23: $1-47$

Steele DH, Whittick A (1991) Seasonal variation in Pilayella littoralis (Phaeophyceae) and its consequences as a food source for the amphipod, Gammarus lawrencianus, in the intertidal of Newfoundland. J Mar Biol Assoc UK 71: 883-889

Vadas RL, Johnson S, Norton TA (1992) Recruitment and mortality of early post-settlement stages of benthic algae. Br Phycol J 27:331-351

Valiela I, Collins G, Kremer J, Lajtha K, Geist M, Seely B, Brawley J, Sham CH (1997) Nitrogen loading from coastal 
watersheds to receiving estuaries: new method and application. Ecol Appl 7:358-380

Warwick RM, Davey JT, Gee JM, George CL (1982) Faunistic control of Enteromorpha blooms: a field experiment. J Exp Mar Biol Ecol 56:23-31

Wilhelmsen U, Reise K (1994) Grazing on green algae by the periwinkle Littorina littorea in the Wadden Sea. Helgol Meeresunters 48:233-242

Worm B, Chapman ARO (1998) Relative effects of elevated grazing pressure and competition by a red algal turf on

Editorial responsibility: John Austin (Assistant Editor), Oldendorf/Luhe, Germany two post-settlement stages of Fucus evanescens C. Ag. J Exp Mar Biol Ecol 220:247-268

Worm B, Lotze HK, Boström C, Engkvist R, Labanauskas V, Sommer U (1999) Marine diversity shift linked to interactions among grazers, nutrients and propagule banks. Mar Ecol Prog Ser 185:309-314

Worm B, Lotze HK, Sommer U (2000) Coastal food web structure, carbon storage, and nitrogen retention regulated by consumer pressure and nutrient loading. Limnol Oceanogr 45:339-349

Submitted: September 10, 1999; Accepted: February 10, 2000 Proofs received from author(s): June 20, 2000 